\title{
CHARISTHEO
}

Jurnal Teologi dan Pendidikan Agama Kristen

Sekolah Tinggi Teologi Anugrah Indonesia

Print ISSN: 2541-5247

http://e-journal.anugrah.ac.id/index.php/JCH

Vol. 1 No. 1, September 2021

Submitted: 2021-08-18

Reviewed: 2021-08-20

Accepted: 2021-08-26

\section{APLIKASI TEORI KECERDASAN MAJEMUK PADA MATA PELAJARAN PAK DI SEKOLAH INKLUSI}

\author{
${ }^{1}$ Sumiati*, ${ }^{2}$ Steaven Octavianus*, ${ }^{3}$ Reni Triposa \\ ${ }^{1-3}$ Sekolah Tinggi Teologi Sangkakala, Salatiga \\ *Email Correspondence: sumi51788@gmail.com
}

\begin{abstract}
In the application of the theory of multiple intelligences to PAK subjects, it is a process of students in knowing the intelligence of students, through the theory it helps students find their intelligence in the learning that has been given. The author uses the library method, it can be concluded that the application of the theory of multiple intelligences Christian religious education is possible. This is done to find out and develop the theory of multiple intelligences through the process of religious education. So that the application of multiple intelligences through Christian religious education includes the concept of multiple intelligences, the availability of time and the ability to utilize learning resources. As well as the ability with the chosen method. because the application of methods to develop one type of intelligence will differ at different levels of development.
\end{abstract}

Keywords : Multiple Intelligences, Christian Education, Religious Education, Inclusion

\begin{abstract}
ABSTRAK
Dalam aplikasih teori kecerdasan majemuk pada mata pelajaran PAK merupakan suatu proses peserta didik dalam mengetahui kecerdasaan yang dimiliki peserta didik, melalui teori tersebut membantu peserta didik dalam menemukan kecerdasaanya dalam pembelajaran yang telah diberikan. Penulis mengunakan metode pustaka dalam kajian ini. Uraian pada artikel ini menyimpulkan aplikasi kecerdasan ganda dapat diimplementasikan dalam pembelajaran pendidikan agama Kristen. Hal ini dilakukan untuk mengetahui dan mengembangkan teori kecerdasan majemuk melalui proses pendidikan agama. Penerapan kecerdasan majemuk melalui pendidikan agama Kristen diantaranya konsep mengenai kecerdasan majemuk, ketersediaan waktu dan kemampuan memanfaatkan sumber belajar, serta kemampuan dengan metode yang dipilih. Karena itu penerapan metode untuk mengembangkan satu jenis kecerdasan akan berbeda pada tingkat perkembangan yang berbeda.
\end{abstract}

Kata kunci : Kecerdasan Majemuk, Pendidikan Kristen, Pendidikan Agama, Inklusi 


\section{PENDAHULUAN}

Sekolah Dasar (SD) merupakan pendidikan formal yang sangat penting, sebagai pondasi bagi pendidikan anak untuk kejenjang yang lebih tinggi. Dalam proses pembelajaran di SD pada semua bidang studi yang diajarkan dalam kelas, diharapkan dapat membantu dalam mengembangkan kemampuan peserta didik, supaya kemampuan yang ada dalam diri mereka dapat menumbuhkan kualitas hidup dari peserta didik itu sendiri. Sehingga peserta didik dapat mengerti dan memahami proses pembelajaran yang ada. Dengan demikian dapat mencapai tujuan pembelajaran secara maksimal. Peserta didik diciptakan dengan berbagai macam keunikan dan karakteristik berbeda-beda yang salah satunya kecerdasan. Peserta didik yang memiliki kecerdasan tinggi akan memiliki kemampuan yang lebih tinggi (Setiawati, 2019). Dalam proses belajar mengajar peserta didik tidak hanya ditentukan dari besarnya angka yang didapat dari penilaian matemtika dan linguistic maupun tingginya tes intellegences (IQ).

Berdasarkan penjelasan yang ada dapat diartikan bahwa kecerdasan merupakan kemampuan dalam menemukan, memecahkan serta menciptakan hal-hal yang baru. Kenyataan yang didapati dalam dunia pendidikan saat ini, banyak guru yang kurang menyadari akan keanekaragaman kemampuan yang dimiliki oleh peserta didik. Melihat keadaan ini perlu yang namanya perbaikkan dalam sistem pembelajaran, yang salah satunya adalah Multiple Intelligences. Peserta didik terbantu dalam meningkatkan kecerdasan dan memperbaiki yang menjadi kekurangannya melalui kelebihan yang dimiliki. Sebagai seorang pengajar atau pendidik merasa terbantu dan dimudahkan dalam mengembangkan bakat dari peserta didik. Meskipun demikian penerapan pembelajaran kecerdasan majemuk (Multiple Intelligences) ini belum banyak diterapkan di sekolah-sekolah, karena belum banyak yang mengetahui konsep pembelajaran yang seperti ini.

Kecerdasan majemuk (Multiple Intelligences) merupakan teori yang membahas tentang kecerdasan pada manusia, mengenai bakat peserta didik dalam menyelesaikan persoalan pembelajaran. Sehingga persoalan yang dihadapi peserta didik dalam proses pembelajaran dapat diselesaikan. Pada tahun 1993 dalam buku yang berjudul Frame of mind: Theory of Multiple Intelligences, teori ini kemudian dikembangkan dan diperkenalkan. Sebelumnya para psikologi tertarik pada kecerdasan yang umum (general intelligences), kemampuan manusia dalam memecahkan masalah, menerapkan ke mampuan logis dan disiplin ilmu (Setiawan, 2005.) Jadi teori ini membahas tentang keberagaman kemampuan atau bisa juga disebut sebagai potensi, bakat 
yang dimilik oleh setiap orang punya itu. Dimana masing-masing potensi atau bakat ini perlu dikembangkan secara menyeluruh, supaya kemampuan yang dimiliki tidak terpendam. Setidaknya ada Sembilan jenis kecerdasan yang termaksud dalam kecerdasan majemuk diantaranya adalah: Kecerdasan linguistik, kecerdasan matematis logis, kecerdasan ruang-visual, kecerdasan kinestetik badani, kecerdasan musical, kecerdasan interpersonal, kecerdasan intrapersonal, kecerdasan lingkungan, kecerdasan eksistensial (Suparno, 2004b, pp. 25-43).

Teori-teori yang menjelaskan tentang kecerdasan majemuk bertola ukur pada sekitar penjelasan mengenai proses belajar bagaimana terjadi. Oleh sebab itu sudah seharusnya para guruguru tidak hanya menggunakan satu metode dalam pengajaran, guru dapat menggunakan berbagai macam model yang berlainan sesuai dengan kecerdasan dari peserta didik, karena peserta didik mempunyai kecerdasan yang berbeda dan peserta didik akan lebih mudah belajar bila metode dalam pembelajaran disajikan sesuai dengan kecerdasan yang menonjol. Pembelajaran dengan pendekatan teori kecerdasan majemuk (multiple intelligences) berfokus pada menemukan keunikan dan kelebihan dari setiap peserta didik (Ibda, 2015a) yang melalui aktivitas atau kegiatan pembelajaran dengan kemampuan kognitif, yang dimana pada tahapan ini anak sudah cukup matang untuk menggunakan pemikiran logika atau operasi, peserta didik berfikir secara konkretnyata, pasti, tepat dan menunjukkan pengalaman secara langsung. Afektif kemampuan untuk menyatakan emosi, dan berdasarkan pengalaman sendiri dalam memenuhi suatu kebutuhan dalam diri anak dan psikomotorik kemampuan dalam berprilaku serta terampil. Mengenai hal-hal ini, peneliti mengkaji aplikasi teori kecerdasan majemuk pada mata pelajaran Pendidikan Agama Kristen di sekolah inklusi. Sehingga dengan menerapkan teori belajar ini, memudahkan guru maupun peserta didik dalam melaksanakan proses belajar mengajar.

Berdasarkan pada paparan di atas penelitian ini bertujuan untuk menganalisis aplikasi teori kecerdasan majaemuk menjadi metode pembelajaran yang dapat diimplementasikan pada mata pelajaran Pendidikan Agama Kristen di sekolah inklusi. Hasil penelitian ini akan memberikan manfaat adanya alternatif metode pembelajaran yang berasal dari kajian teori kecerdasan majemuk. Metode pembelajaran ini adalah pengejawantahan nyata dari teori kecerdasan majemuk yang menjadi manfaat praktis dalam pembelajaran Agama Kristen di sekolah inklusi. 


\section{METODE PENELITIAN}

Metode penelitian yang akan digunakan adalah metode kualitaitif deskriptif (Zaluchu, 2020), analisis konten dengan pendekatan kualitatif (Arikunto., 2009, p. 244). Sedangkan teknik pengumpulan data dalam penelitian ini adalah studi pustaka (Library Research). Menurut ahli lain studi kepustakaan merupakan kajian teoretis, referensi serta literatur ilmiah lainnya yang berkaitan dengan budaya, nilai dan norma yang berkembang pada situasi sosial yang diteliti (Akbar et al., 2020). Penulis juga menggunakan sumber-sumber acuan yang dapat melengkapi penelitian ini yang masih dianggap menjadi sumber penunjang. Penulis menggunakan beberapa sumber sekunder yang membahas tentang pengaplikasikan teori kecerdasan majemuk dengan tema dan topik yang dibahas dalam penulisan tersebut. Dan setiap kata yang berhubungan dengan aplikasi teori kecerdasan majemuk dengan mata pelajaran pendidikan agama krsiten ditelusuri dengan literatur pustaka buku-buku terbaru dan terbitan jurnal untuk menambah penelitian pustaka ini. Dari makna literal maupun makna kontekstual, maka dapat disusun aplikasi teori kecerdasan majemuk, pendidikan agama kristen yang dapat dituangkan secara deskriptif untuk mencapai tujuan penulisan.

\section{PEMBAHASAN}

\section{Teori Kecerdasan Majemuk}

Teori kecerdasan majemuk (Multiple Intelligences atau MI) ditemukan dan dikembangkan oleh Howard Gardner, seorang ahli psikologi perkembangan dan professor pendidikan dari Graduate School of Education, Harvard University, Amerika Serikat. Ia memulai menulis gagasannya tentang kecerdasan majemuk dalam bukunya Frames of Mind pada tahun 1983 (Suparno, 2007, p. 17). Gardner berpendapat bahwa kecerdasan sebagai kemampuan untuk memecahkan persoalan dan menghasilkan produk dalam suatu setting yang bermacam-macam dan dalam situasi yang nyata (Gardner, 2003, p. 24). Kecerdasan bukanlah kemampuan seseorang untuk menjawab soal-soal tes IQ dalam ruang tertutup yang terlepas dari lingkungannya. Akan tetapi, kecerdasan memuat kemampuan seseorang untuk memecahkan persoalan yang nyata dan dalam situasi yang bermacam-macam. Seseorang memiliki kecerdasan yang tinggi apabila ia dapat menyelesaikan persoalan hidup yang nyata, bukan hanya dalam teori. Semakin seseorang terampil dan mampu menyelesaikan persoalan kehidupan yang situasinya bermacam-macam dan kompleks, semakin tinggi kecerdasannya (Chatib, 2009, p. 89). 
Kecerdasan merupakan salah satu faktor utama yang menentukan sukses gagalnya peserta didik dalam belajar. Peserta didik yang mempunyai taraf kecerdasan rendah atau dibawah rata-rata sangat sukar diharapkan bermotivasi tinggi. Tetapi tidak ada jaminan bahwa dengan taraf kecerdasan tinggi seseorang secara otomatis akan sukses belajar di sekolah (Munif Chatib, 2010). Berbagai ilmu dari Gardner yang telah menemukan teori kecerdasan majemuk atau multiple intelligences bahwa ada banyak kecerdasan yang dimiliki setiap orang. Teori ini juga menekankan pentingnya model atau teladan yang sudah berhasil mengembangkan salah satu kecerdasan hingga puncak (Djaali, 2007, p. 73).

\section{Perbandingan Dengan Teori Tecerdasan Lain}

Teori kecerdasan majemuk adalah validasi tertinggi gagasan bahwa perbedaan individu adalah penting. Pemakaiannya dalam pendidikan sangat tergantung pada pengenalan, pengakuan dan penghargaan terhadap setiap atau berbagai peserta didik belajar, di samping pengenalan, pengakuan dan penghargaan terhadap minat dan bakat setiap masing-masing peserta didik. Teori kecerdasan majemuk bukan hanya mengakui perbedaan individual untuk tujuan-tujuan praktis seperti pengajaran dan penilaian, tetapi juga menganggap serta menerimanya sebagai sesuatu yang wajar, normal, bahkan menarik dan sangat berharga (Jasmine, 2007, p. 13). Kecerdasan majemuk yang meliputi tujuh kecerdasan yaitu: kecerdasan musik, kecerdasan gerak-badan, kecerdasan logika-matematika, kecerdasan linguistik, kecerdasan ruang, kecerdasan antarpribadi, kecerdasan intrapribadi. Teori ini mengambarkan beberapa kemampuan yang berpusat pada keterampilan dari suatu kecerdasan tertentu. Sehingga dapat di optimalkan sebaik mungkin. Semakin berkembangnya zaman, kemudian ditemukan lagi bahwa kecerdasan pada manusia bukan hanya tujuh. Melainkan ada delapan kecerdasan yang ada pada manusia (Jasmine, 2007, p. 13).

Gardner dalam bukunya Jasmine mengenalkan teori kecerdasan majemuk yang menyatakan bahwa kecerdasan meliputi delapan kecerdasan. Yaitu kecerdasan linguistik, kecerdasan matematis-logis, kecerdasan ruang-visual, kecerdasan kinestetik-badani, kecerdasan musical, kecerdasan interpersonal, kecerdasan intrapersonal, kecerdasan lingkungan. Teori tersebut didasarkan pada pemikiran bahwa kemampuan intelektual yang diukur melalui tes IQ sangatlah terbatas, karena tes IQ hanya menekankan pada kemampuan logika (matematika) dan Bahasa. Padahal setiap orang mempunyai cara yang unik untuk menyelesaikan persoalan yang dihadapinya. Kecerdasan bukan hanya dilihat dari nilai yang diperoleh seseorang (Jasmine, 2007, p. 14). 
Kecerdasan merupakan kemampuan yang dimiliki oleh seseorang untuk melihat suatu masalah, lalu menyelesaikan masalah tersebut atau membuat sesuatu yang berguna bagi orang lain.

Dengan menerapkan kecerdasan majemuk, maka aktivitas mengajar adalah ibarat air yang menigisi ruang-ruang murid. Ketika murid diibaratkan bagaikan botol, maka seorang pendidik dituntut untuk mampu menyesuaikan seperti botol; dan ketika murid ibaratseperti gelas, maka seorang pendidik juga dituntut dapat mengikuti seperti gelas. Artinya dengan bekal kecerdasan majemuk, aktivitas mengajar harus sesuai dengan gaya belajar setiap individu peserta didik. Mengembangkan kecerdasan majemukpeserta didik merupakan kunci utama untuk kesuksesan dari peserta didik (Lwin, 2005, p. 5). Dengan mempertimbangkan dan melihat cara belajar yang paling menonjol dan masing-masing individu, maka seorang pendidik atau orang tua diharapkan dapat bertindak secara aktif dan bijaksana dalam memilih gaya mengajar yang sesuai dengan gaya belajar peserta didik.

Apabila diperhatikan secara cermat teori tentang kecerdasan majemuk, sebenarnya merupakan fungsi dari dua belahan otak manusia, yakni otak kanan dan otak kiri. Otak kiri memiliki kemampuan dan potensi untuk memecahkan masalah problem matematik, logis dan fenomenal. Sedangkan otak kanan memiliki kemampuan untuk merespon hal-hal yang bersifat kualitatif, artistic dan abstrak, tetapi tetap harus diingat bahwa ini semua masih dalam kerangka kemampuan terhadap dunia luar, sedangkan pengetahuan tentang diri, belum dijangkau (Suharsono, 2004, p. 47). Suharsono menyebutkan bahwa temuan Gardner tentang kecerdasan majemuk ini banyak diadaptasi oleh berbagai pihak, karena fungsinya sebagai deteksi dini terhadap bakat intelektual (gifted) maupun seni (talented). Tidak kurang dari teori quantum (quantum learning) juga merujuk pada pola kecerdasan ini. Begitu juga dengan berbagai bidang lainnya, karena dengan sistem kecerdasan majemuk Gardner, dimungkinkan penjaringan dan penyaringan anak-anak berbakat, yang kemudian hari diharapkan memberi kontribusi yang signifikan bagi keunggulan dan dorongan manusia (Suharsono, 2004, p. 48).

Pembelajaran berbasis kecerdasan majemuk secara umum dapat diartikan sebagai proses pembelajaran yang memberi ruang gerak bagi setiap individu peserta didik untuk mengembangkan potensi kecerdasannya. Peserta didik dituntut agar dapat belajar secara enjoy, tidak dengan rasa keterpaksaan, dan memiliki motivasi atau dorongan yang tinggi. pada hakikatnya, pembelajaran berbasis kecerdasan majemuk dapat juga dimaknai sebagai pembelajaran yang membiarkan anak didik untuk selalu kreatif, tentunya, kreativitas yang dibangun adalah bentuk kekreatifan yang 
dapat mendukung terhadap keberlangsungan proses pembelajaran dengan menghasilkan terget motivasi akademik yang membanggakan. Terlebih memiliki kriteria dalam penguasaan materi pembelajaran sebagai dampak dari proses pembelajaran tersebut (Setiyowati \& Arifianto, 2020). Hal itu diharapkan mampu menjadi sumber inspirasi dan motivasi, maka hal itu akan membawa semangat perubahan untuk menjadi manusia yang menjadi berkat (Triposa et al., 2021).

\section{Jenis Kecerdasan Majemuk}

Menurut penelitian, Gardner mengumpulkan banyak jenis kemampuan manusia yang dapat dikategorikan sebagai kecerdasan. Untuk menunjang keberhasilan pembelajaran pada dasarnya adalah menentukan pendekatan pembelajaran yang sejalan dengan kurikulum tersebut. Membahas pendekatan pembelajaran, banyak sekali jenis pendekatan yang dapat diterapkan. Di antaranya pendekatan pembelajaran yang dikembangkan dari suatu teori yang dikenal dengan teori kecerdasan majemuk. Teori tersebut digunakan sebagai pendekatan pembelajaran, karena di dalamnya membicarakan tentang keberagaman yang saling terkait dengan kompetensi peserta didik.

Pada dasarnya setiap kurikulum menitikberatkan pada pencapaian utau kompetensi tertentu peserta didik. Pendekatan kecerdasan majemuk pun memandang bahwa seseorang atau manusia memiliki beberapa potensi kecerdasan. Salah satu dari kecerdasan setiap peserta didik itulah yang harus dikembangkan, sehingga pada akhirnya menjadi suatu kompentensi yang sangat dominan dikuasainya. Gardner dengan bukunya yang berjudul Frames of Mind; the Theory of Multiple Intelligens, sebagaimana dikutip Paul Suparno membagi kecerdasan manusia dalam 7 kategori, dan kemudian berkembang menjadi 9 kategori yaitu: Kecerdasan Bahasa (linguistic intelligences). Gardner menjelaskan kecerdasan Bahasa merupaka kemampuan seseorang dalam menggunakan dan megelola kata-kata baik secara lisan maupun tulisan, untuk mengambarkan ide atau gagasan yang dimiliki (Baharuddin, 2015, p. 203). Orang yang mempunyai kecerdasan berbahas tinggi akan mampu berbahasa dengan lancar, baik dan lengkap. Ia mudah untuk mengetahui dan mengembangkan Bahasa dan mudah mempelajari berbagai Bahasa. Kecerdasan Matematika (logic-matematis intelligences). Menurut Gardner, kecerdasan matematika adalah kemampuan yang berkaitan dengan penggunaan bilangan dan logika secara efektif (Suparno, 2004b, p. 29). Termasuk dalam kecerdasan ini adalah kepekaan pada pola logika, abstraksi, kategorisasi, dan perhitungan. Orang yang kuat dalam hal kecerdasan logis matematis mempunyai keterampilan 
berpikir kritis untuk merangkai, menghubungkan, menganalisis suatu data. Kecerdasan Ruang Visual (spatial intelligences).

Kecerdasan ruang atau inteligences ruang visual adalah kemampuan untuk menangkap dunia ruang-visual secara tepat, seperti yang dimiliki oleh seorang decorator dan arsitek (Harmoni \& Theis, 2012). Yang termasuk di dalamnya adalah kemampuan untuk mengenal bentuk dan benda secara tepat, melakukan perubahan bentuk benda dalam pikiran dan mengenali perubahan tersebut, menggambarkan suatu hal atau benda dalam pikiran dan mengubahnya dalam bentuk nyata serta mengungkapkan data dalam suatu grafik. Kecerdasan Gerak Badani (bodily-kinesthetic intelligences). Kecerdasan gerak badani, menurut Gurdner, merupkan kemampuan seseorang untuk secara aktif menggunakan bagian-bagian atau seluruh tubuhnya untuk berkomunikassi dan memecahkan masalah (Dara, n.d., pp. 42-51). Orang yang mempunyai kecerdasan ini dengan mudah dapat mengungkapkan diri dengan gerak tubuh mereka. Apa yang mereka pikirkan dan rasakan dengan mudah diekspresikan melalui gerak tubuh. Kecerdasan Musikal (musical intelligences). Gardner menjelaskan, kecerdasan musical merupakan kemampuan seseorang untuk mengembangkan dan mengekspresikan, menikmati bentuk-bentuk music dan suara, peka terhadap ritme, melodi dan intonasi serta kemampuan memainkan alat music, menyanyi, menciptakan lagu dan menikmati lagu (Suarca, 2005). Merekapun pintar melantunkan bait lagu dengan baik dan benar, menggunakan kosa kata musikal, dan peka terhadap ritme, ketukan, melodi atau warna suara dalam sebuah potongan komposisi musik.

Kecerdasan Interpersonal (interpersonal intelligences). Kecerdasan interpersonal adalah kemampuan seseorang untuk mengerti dan menjadi peka terhadap perasaan, motivasi, watak, temperamen, ekspresi wajah, suara dan isyarat dari orang lain (Gardner, 2002, p. 48). Secara umum, kecerdasan interpersonal merupakan kemampuan seseorang untuk menjalin relasi dan komunikasi dengan orang lain. Kecerdasan Intrapersonal (intrapersonal intelligences). Kecerdasan intrapersonal merupakan kemampuan seseorang untuk mengerti diri sendiri dan mampu bertindak secara adaptative berdasarkan pengenalan diri (Evelyn Wiliams English, n.d., p. 142). Termasuk dalam kecerdasan intrapersonal adalah kemampuan berefleksi dan menyeimbangkan diri, mempunyai kesadaran tinggi akan gagasan-gagasan, mempunyai kemampuan mengambil keputusan pribadi, sadar akan tujuan hidup dapat mengendalikan emosi sehingga kelihatan sangat tenang. Orang yang mempunyai kecerdasan intrapersonal akan dapat berkonsentrasi dengan baik. Kecerdasan lingkungan/Natural (natural intelligences). 
Gardner menjelaskan kecerdasan lingkungan sebagai kemampuan seseorang untuk dapat mengerti flora dan fauna dengan baik, dapat memahami dan menikmati alam dan menggunakannya secara produktif dalam Bertani, berburu dan mengembangkan pengetahuan akan alam (Evelyn Wiliams English, n.d., p. 180). Orang yang mempunyai kecerdasan lingkungan atau natural memiliki kemampuan untuk tinggal diluar rumah, dapat berhubungan dan berkawan dengan baik. Kecerdasan Eksistensial (existensial intelligences). Kecerdasan eksistensial lebih pada kepekaan dan kemampuan seseorang dalam menjawab persoalan-persoalan terdalam mengenai eksistensi manusia. Orang yang mempunyai kecerdasan eksistensi mencoba menyadari dan mencari jawaban yang terdalam. Pertanyaan yang muncul adalah mengapa aku ada? Mengapa aku mati? Apa makna hidup ini? Bagaimana manusia sampai ketujuan hidup? (Sustainable, 2019). Sama seperti kecerdasan lainnya, kecerdasan ini mulai muncul pada awal masa kanak-kanak. Karena anakanak belum mempunyai penyaring kebudayaan seperti orang dewasa, mereka selalu dapat menerima rahasia kehidupan dan secara terus menerus mengajukan pertanyaan besar yang sulit dijawab oleh orang dewasa di sekitarnya. Kecerdasan Spiritual (spiritual intelligences). Pada tahun 1990-an, penelitian oleh Michael Persinger dan V.S. Ramachandran menemukan adanya titik ketuhanan (God-spot) dalam otak manusia. Daerah ini berlokasi pada penghubungan saraf pada lobus temporal otak. Tanpa kecerdasan spiritual, kemampuan manusia tidak dapat mencapai potensi yang penuh. Kecerdasan spiritual merupakan akses manusia menggunakan makna, visi, dan nilai-nilai dalam jalan yang pikiran dan keputusan yang dibuat. Dengan kecerdasan spiritual manusia menyadari dengan sumber daya yang tersedia bagi mereka, manusia menemukan kebebasan dari keterbatasan sebagai manusia dan mencapai keilahian (Hasan, 2006, p. 312).

Jika dikaitkan kesepuluh kecerdasan yang dimiliki manusia tersebut dalam pembelajaran, maka dapat disimpulkan bahwa sebaiknya kecerdasan majemuk digunakan dan diterapkan sebagai pendekatan pelaksanaan kegiatan pembelajaran. Setiap manusia atau peserta didik tentu akan memiliki potensi yang sesuai dengan salah satu kecerdasan diatas. Dengan demikian, maka diharapkan salah satu potensi kompentensi dari peserta didik dapat muncul dan dapat dikembangkan. Kecerdasan majemuk yang mencakup sepuluh kecerdasan itu pada dasarnya merupakan penggembangan dari kecerdasan otak (IQ), kecerdasan emosional (EQ), kecerdasan spiritual (SQ). semua jenis kecerdasan perlu dirangsang pada diri anak sejak usia dini, mulai dari saat lahir hingga awal memasuki sekolah (7-8 tahun). Salah satu hal yang perlu diperhatikan dalam kecerdasan majemuk adalah adanya tanggung jawab lembaga-lembaga pendidikan, dan kecerdikan 
seorang guru dalam memperhatikan bakat masing-masing peserta didik. Di dalam maupun di luar sekolah, setiap peserta didik harus berhasil menemukan paling tidak satu wilayah kemampuan yang sesuai dengan potensi kecerdasannya. Jika hal itu berhasil ditemukan oleh peserta didik dengan bimbingan guru, maka akan menimbulkan kegembiraan dalam proses pembelajaran, bahkan akan membangkitkan ketekunan dalam upaya-upaya penguasaan disiplin keilmuan tertentu.

\section{Penerapan Kecerdasan Majemuk}

Penerapan dengan pendekatan kecerdasan majemuk dalam pembelajaran, harus memperhatiak beberapa langkah, meliputi: Mengidentifikasi elemen-elemen kecerdasan majemuk pada program kurikuler dan ekstrakulikuler. Misalnya memasukkan program seni ke dalam kurikulum. Meninjau kembali sistem teknologi dan program piranti lunak untuk melihat kecerdasan-kecerdasan apa yang terabaikan. Para guru merenungkan kemampuan peserta didik, kemudian memutuskan untuk secara sukarela bekerjasama dengan rekan-rekan yang lain. Proses pembelajaran dengan tanggung jawab tertentu, bisa dipilih sebagai metode pembelajaran. Diskusi dengan orang tua peserta didik dan anggota masyarakat sehingga dapat membuka kesempatankesempatan magang bagi para peserta didik (Suparno, 2004a, p. 78).

Di samping langkah-langkah di atas, sebagai upaya untuk memadukan pendekatan kecerdasan majemuk dalam pembelajaran, perlu juga memerhatikan hal-hal berikut: Persepsi tentang peserta didik harus diubah selama ini orang selalu memiliki persepsi terhadap peserta didik, bahwa peserta didik itu cerdas, rata-rata, dungu, dan lain-lain. Persepsi inilah yang harus diubah. Sebaiknya para pendidik memberikan perhatian kepada berbagai macam cara yang dilakukan peserta didik untuk memecahkan masalah-masalah mereka dan mengaplikasikan apa yang telah mereka pelajari. Guru harus menerima bahwa peserta didik memiliki profil-profil kognitif dengan tingkat kemampuan yang berbeda-beda. Guru harus menyediakan kesempatan-kesempatan observasi mereka, mengumpulkan informasi tentang bakat dan kegemaran peserta didik, serta mempelajari kecerdasan-kecerdasan yang tidak biasa. Guru membutuhkan dukungan dan waktu untuk memperluas daftar pengajaran mereka. Jika proses pembelajaran ingin mencapai tujuan bahwa peserta didik harus memiliki pengetahuan, nilai dan sikap, serta keterampilan yang seimbang, maka jam belajar yang selama ini hanya cukup untuk menguasai pengetahuan saja harus diubah dengan memperluas jam belajar hal ini perlu dilakukan tidak lain untuk: Memberi dukungan dan melakukan praktik. Meminta guru tertentu yang memiliki kemampuan tinggi dalam sebuah 
kecerdasan untuk memberikan pelatihan. Mengintegrasikan para spesialis yang memiliki keahlian dalam bidang tertentu. Mengunjungi lokasi-lokasi sebagai bahan perbandingan proses pembelajaran. Pendekatan kecerdasan majemuk dan pembelajaran. Kurikulum pada dasarnya berfokus pada pengetahuan yang mendalam dan pengembangan kemampuan. Dalam hal ini, pembelajaran tidak harus menekankan pengajaran melalui kecerdasan, tetapi yang harus mendapat penekanan adalah bahwa pembelajaran itu untuk kecerdasan atau penguasaan kompentensi tertentu sesuai dengan minat dan bakat peserta didik. Diperlukan pendekatan baru terhadap proses penilaian. Ada beberapa hal yang perlu diperhatikan dalam aktivitas penilaian, yaitu: Bagaimana menilai kecerdasan peserta didik; Bagaimana meningkatkan penilaian secara umum dalam hal kognitif, afektip dan psikomotorik; Bagaimana melibatkan peserta didik dalam proses penilaian. Praktik professional menuju kearah perkembangan. Tingkat profesionalisme para pendidik perlu dimiliki setiap guru, sehingga tantangan yang dihadapi tertama dalam menentukan model program yang akan dilakukan di kelas, tepat dan sesuai dengan kompentensi peserta didik (Suparno, 2004a, p. 79).

\section{Sekolah Inklusi}

Inklusi berasal dari kata inclusion yang berarti penyatuan. Inklusi mendeskripsikan sesuatu yang positif dalam usaha-usaha menyatukan anak-anak yang memiliki hambatan dengan cara yang realistis dan komprehensif dalam kehidupan pendidikan yang menyeluruh (Smith, 2006, p. 45). Sapon-Shevin berpendapat bahwa, pendidikan inklusi merupakan sistem layanan pendidikan luar biasa yang mempersyaratkan agar semua anak luar biasa dilayani di sekolah-sekolah terdekat di kelas biasa bersama. Pendekatan inklusi merupakan layanan pendidikan yang disesuaikan dengan kebutuhan-kebutuhan khusus anak secara individual dalam pembersamaan klasikal. Stainback dan Stainback dalam buku Sunardi, berpendapat bahwa sekolah inklusi adalah sekolah yang menampung semua murid di kelas yang sama (Sunardi, 2003). Sekolah ini menyediakan program pendidikan yang layak, menantang, tetap sesuai dengan kemampuan dan kebutuhan setiap peserta didik maupun bantuan dan dukungan yang dapat diberikan oleh para guru agar anak-anak berhasil (Stainback, 1995, p. 44). Lebih dari itu sekolah inklusi juga merupakan tempat setiap anak dapat diterima, menjadi bagian kelas tersebut dan saling membantu dengan guru dan teman sebayanya, maupun anggota masyarakat lain agar kebutuhan dapat terpenuhi. Inklusi mempunyai arti yang berbeda-beda bagi tiap orang. Menurut Fuchs dan Fuchs dalam buku Smith, Sebagian bahkan 
menggunakan istilah inklusi sebagai banner untuk menyerukan "full inclusion" atau “uncompromising inclusion” yang berarti penghapusan pendidikan khusus (Smith, 2006, p. 38). Sekolah inklusi merupakan sekolah yang menyediakan dan menampung anak-anak berkebutuhan khusus untuk dididik dilingkungan sekolah biasa dengan anak-anak lain yang normal (Tarmansyah, 2007, p. 76). Sehingga anak-anak yang berkebutuhan khusus memperoleh pendidikan yang sama dengan anak pada umumnya.(Darma \& Rusyidi, 2003)

Sekolah inklusi dimulai dengan filosofi bahwa semua anak dapat belajar dan tergabung dalam sekolah dan kehidupan komunitas umum. Pendidikan inklusi adalah bentuk pelayanan pendidikan khusus yang mensyaratkan agar semua anak berkebutuhan khusus dapat menerima pendidikan setara dikelas biasa bersama dengan teman-teman seusianya. Mujito berpendapat bahwa, di sekolah inklusi anak berkebutuhan khusus dapat berinteraksi langsung dengan anak yang normal (Septianisa \& Caninsti, 2016). Sedangkan menurut pendapat Baihaqi dan Sugiarmin menyatakan bahwa hakikat inklusi adalah mengenai hak setiap peserta didik atas perkembangan individu, sosial, dan intelektual. Para peserta didik harus diberi kesempatan untuk mencapai potensi mereka. Untuk mencapai potensi tersebut, sistem pendidikan harus dirancang dengan memperhitungkan perbedaan-perbedaan yang ada pada diri peserta didik. Oleh karena itu keberagaman yang terjadi disuatu masyarakat adalah sesuatu yang lumrah atau normal, keberagaman individu yang terjadi di masyarakat dapat berupa perbedaan, sosial kultural, sosioemosional, kelainan fungsi anggota tubuh, kelainan fungsi mental dan sebagainya (Sofiah, 2006, p. 29).

Di Indonesia kebijakan pendidikan untuk anak berkebutuhan khusus diatur melalui Undang-Undang No. 20 Tahun 2003 tentang Sistem Pendidikan Nasional. Secara khusus dalam undang undang tersebut dinyatakan bahwa warga negara yang memiliki kelainan fisik, emosional, mental dan atau sosial berhak memperoleh pendidikan khusus dan penyelenggaraannya dilakukan secara inklusif atau berupa satuan pendidikan khusus (SISDIKNAS, 2003). Kemudian pelaksanaan pendidikan inklusi diatur dalam Peraturan Menteri Pendidikan Nasional Nomor 70 tahun 2009. Dalam Permendiknas RI No. 70 tahun 2009 pasal 1, pendidikan inklusi didefinisikan sebagai sistem penyelenggaraan pendidikan yang memberikan kesempatan kepada semua peserta didik yang memiliki kelainan dan memiliki potensi kecerdasan dan bakat istimewa untuk mengikuti pendidikan atau pembelajaran dalam suatu lingkungan pendidikan secara bersama-sama dengan peserta didik pada umumnya (Saputra, 2016). Secara konseptual model pendidikan inklusi 
menjanjikan sejumlah keunggulan dalam penyelenggaraan bagi anak berkebutuhan khusus, pendidikan inklusi dianggap merupakan strategi yang efektif untuk menuntaskan wajib belajar sembilan tahun bagi anak berkebutuhan khusus.

\section{Kecerdasan Majemuk di Sekolah Inklusi Pada Mata Pelajaran Pendidikan Agama Kristen}

Aset terbesar dan paling bernilai disebuah sekolah adalah guru yang berkualitas. Sebaik apapun kurikulumnya, sulit berhasil apabila tidak dijalankan dengan strategi pembelajaran yang menarik, menyenangkan, dan mampu menginspirasi anak didiknya (Munif Chatib, 2010, p. 69). Kendala bagi dunia pendidikan untuk menghasilkan lulusan yang berkualitas adalah prestasi anak didik hanya diukur dari kemampuan kecerdasan intelektual yang menekankan pada kemampuan matematika dan bahasa. Kecerdasan intelektual tidak hanya mencakup dua parameter tersebut di atas, tetapi juga harus dilihat dari aspek kinestetik, musikal, visual-spasial, interpersonal, intrapersonal, dan naturalis. Pada tahun 1983 Gardner memperkenalkan 8 jenis kecerdasan, yaitu: matematika logika, bahasa, kinestetik, musik, visual-spasial, interpersonal, intrapersonal, dan naturalis. Pada tahun 1999 dengan perkembangan pemikirannya, Gardner menambahkan satu kecerdasan lagi yaitu kecerdasan eksistensial (Gardner, 2003, p. 23). Jenis-jenis kecerdasan intelektual tersebut dikenal dengan sebutan kecerdasan jamak (Multiple Intelligences) yang diperkenalkan oleh Howard Gardner pada tahun 1983. Gardner mengatakan bahwa kita cenderung hanya menghargai orang-orang yang memang ahli di dalam kemampuan logika (matematika) dan bahasa. Kita harus memberikan perhatian yang seimbang terhadap orang-orang yang memiliki talenta (gift) di dalam kecerdasan yang lainnya seperti artis, arsitek, musikus, ahli alam, designer, penari, terapis, entrepreneurs, dan lain-lain (Gardner, 2002, p. 25).

Pendidikan inklusi adalah pendidikan berkeadilan yang dilindungi undang-undang karena pada dasarnya hakikat manusia adalah berfikir. Aguste Rodin memberikan ilustrasi mengenai berfikir lewat karya patung termasyhurnya di prancis. Rodin mengambarkan patung tersebut sebagai homo sapiens, manusia yang berfikir. Setiap saat hidup sejak lahir hingga liang lahat, manusia tidak pernah berhenti untuk berfikir (Jujun S, 2001, p. 1). Pendidikan berkeadilan merupakan pendidikan yang mengakomodasi serba ada kecerdasan pada setiap manusia, dengan beraneka ragamnya kecerdasan dan kemampuan belajar, kemampuan masing-masing anak dapat digali dengan pendekatan gaya belajar yang tepat. Oleh karena itu sangat penting bagi guru mengenali gaya belajar peserta didik karena guru sebagai fasilitator dan katalisator, mengajar 
dengan menyesuaikan gaya belajar peserta didik dan selalu mematikan rasa ingin tahu peserta didik. Jika ditelusuri, penyebab seorang anak dianggap bermasalah adalah saat anak gagal mencerna informasi ketika belajar.

Pendidikan inklusi memiliki korelasi dengan Multiple Intelligences, karena sistem ini lebih menekankan pada proses pengajaran berkualitas dari pada penerimaan peserta didik baru yang memenuhi kuota saat seleksi dan kelulusan peserta didik yang "tidak adil". Proses pengajaran berkualitas akan berorientasi pada "bukan sebesar apa kecerdasan anda, melainkan bagaimana anada menjadi cerdas (Chatib, 2012, p. 51). Pendidikan inklusi berarti menyiapkan dan mendorong guru untuk belajar interaktif. Perubahan dalam kurikulum berkaitan erat dengan perubahan metode pembelajaran. Model kelas tradisional, di mana seorang guru secara sendiri berjuang untuk dapat memenuhi kebutuhan semua anak di kelas harus diganti dengan model pembelajaran bekerja sama, saling mengajar dan secara aktif berpartisipasi dalam pendidikannya sendiri dan teman-temannya berkaitan dengan pembelajaran kooperatif. Kooperatif dan kelas inklusi sekarang jelas, semua anak berada dalam satu kelas bukan untuk berkompetensi, tetapi untuk bekerja sama dan saling belajar dari yang lain. Konsep multiple intelligences sangat tepat dalam implikasinya di kelas inklusi. Seseorang yang kuat disatu dimensi mungkin lemah pada dimensi yang lain (Santoso, 2012, p. 29). Dalam pembelajaran kecerdasan berbasisi majemuk ini adalah sebuah proses pembelajaran dimana tidak lagi sebuah model pembelajaran menggunakan metode ceramah, dan hanya terfokus pada pendidik (guru) yang menyampaikan ilmu kemudian peserta didik itu sendiri yang menerimanya, tanpa harus mengetahui bagaimana proses pembelajaran yang bisa dipahami dan diterima oleh peserta didik itu sendiri, namun disini menjelaskan bahwa proses pembelajaran pendidikan agama yang berbasis kecerdasan majemuk (Multiple Intelligence), ini sebuah proses pembelajaran yang sesuai dengan bakat dan minatnya, sepeti halnya manusia yang baru diciptakan, yaitu sesuai dengan kejadiannya (Ma'arif \& Sulistyanik, 2019).

Pendidikan Agama Kristen sebagai sebuah mata pelajaran pada lembaga formal memiliki peran dalam menanamkan fondasi pemahaman karakter spiritual kepada siswa. Secara eksplisit Pendidikan Agama Kristen memiliki hubungan erat dengan kecerdasan majemuk. Salah satu bentuk kecerdasan majemuk adalah kecerdasan spiritual. Pendidikan Agama Kristen sebagai rumpun keilmuan pendidikan agama merupakan Pendidikan yang mengajarkan mengenai spiritualitas agama Kristen pada siswa. Selain daripada itu Pendidikan Agama Kristen juga mengajarkan aturan dan norma Kekristenan serta keimanan bagi para peserta didiknya. Dalam 
konteks Indonesia pembelajaran agama merupakan hal yang fundamental bagi para penganutnya. Sila Pertama dalam Pancasila sebagai dasar negara mengatur mengenai ke-Tuhanan. Pembelajaran Pendidikan Agama Kristen bagi peserta didik di sekolah inklusi akan menemui tantangan tersendiri (Pratiwi, 2015). Hal ini disebabkan di sekolah inklusi kondisi para murid berbeda satu dengan lainnya. Keanekaragaman perkemabangan fisiologis dan psikologis menjadi variabel yang tidak dapat dihindari lagi.

Untuk itu diperlukan adanya metode praktis yang dapat membantu guru untuk bisa mengajarkan Pendidikan Agama Kristen di sekolah inklusi. Pembelajaran di sekolah inklusi perlu penyesuaian dengan kebutuhan para siswa (Fajra, dkk, 2020). Pendidikan Agama Kristen yang mengajarkan refleksi tentang keimanan Kristen tentu juga perlu melakukan hal tersebut. Teori kecerdasan majemuk memungkinkan pengajar untuk dapat mengkreasikan pembelajaran yang aktif di mana peserta didik yang beragam bisa terlibat penuh dalam pembelajaran sesuai dengan kecerdasan masing-masing. Pembelajaran yang efektif juga dapat terlaksana mengingat metode akan diberikan sesuai dengan kebutuhan peserta didik yang ada.

Pembelajaran yang dikembangkan oleh guru Pendidiakn Agama Kristen juga dapat menjadi menyenangkan mengingat para siswa akan dapat terlibat sesuai dengan bakat dan minat siswa. Dengan demikian guru akan dapat membawa siswa mengalami pengalaman yang berbeda dalam mempelajari Agama Kristen. Perenungan spiritualitas akan membawa pada perjalanan kerohanian pribadi siswa. Metode yang adaptif ini juga dipakai oleh Tuhan Yesus dalam mengajar orang banyak yaitu mengajar melalui perumpamaan yang dapat dimengerti oleh orang banyak pada masa itu. Teori kecerdasan majemuk ini akan menjadi sebuah metode empiris yang dapat membantu guru mengenali siswa nya yang beraneka ragam sehingga metode inovatif dan kreatif dalam pembelajaran Pendidikan Agama Kristen dapat dilaksanakan. 
Secara garis besar akan digambarkan dalam Gambar 1.1 berikut:

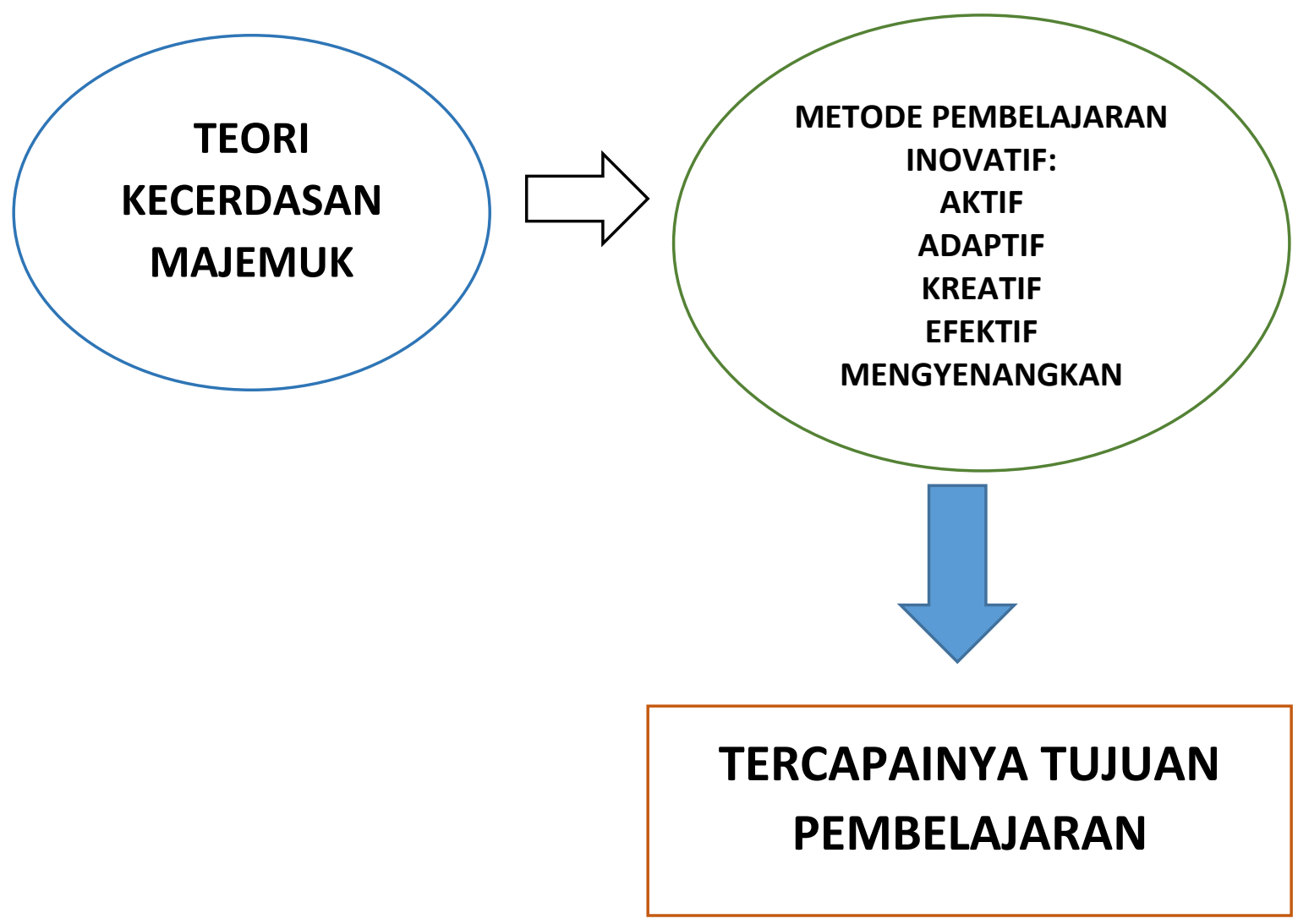

Gambar 1.1 Aplikasi Teori Kecerdasan Majemuk dalam Pendidikan Agama Kristen di Sekolah Inklusi 


\section{KESIMPULAN}

Berdasarkan apa yang telah dipaparkan mengenai penjelasan di atas, sebagaimana dijelaskan didalam teori Howard Gardner untuk mengetahui banyak kecerdasaan yang dimiliki oleh setiap individu. Menurutnya ada 9 jenis inteligensi, yakni linguistic, logis-matematis, spasial, musik, gerak-badani, interpersonal, imtrapersonal, naturalis atau lingkungan dan eksistensial. Kesembilan kecerdasan tersebut perlu dikembangkan secara maksimal sejak usia dini, minimal sejak usia sekolah dasar agar bermanfaat bagi individu yang bersangkutan. Ada beberapa hal yang perlu diperhatikan dalam penerapan kecerdasan majemuk melalui pendidikan agama Kristen diantaranya konsep mengenai kecerdasan majemuk, ketersediaan waktu dan kemampuan memanfaatkan sumber belajar. Serta kemampuan dengan metode yang dipilih. karena penerapan metode untuk mengembangkan satu jenis kecerdasan akan berbeda pada tingkat perkembangan yang berbeda. 


\section{REFERENSI}

Akbar, T., Anto, P., \& Andrijanto, M. S. (2020). Mural As a Medium of Language Learning in Preschool Education. Hortatori : Jurnal Pendidikan Bahasa Dan Sastra Indonesia, 4(1), 6672. https://doi.org/10.30998/jh.v4i1.319

Arikunto. (2009). Manajemen Penelitian. Rineka Cipta.

Baharuddin, H. (2015). Teori Belajar dan Pembelajaran. AR-RUZZ MEDIA.

Chatib, M. (2009). Sekolahnya Manusia: Sekolah Berbasis Multiple Intelligences di Indonesia. PT Mizan Pustaka.

Chatib, M. (2012). Sekolah anak-anak Juara Berbasis Kecerdasan Jamak dan Pendidikan Berkeadilan. PT Mizan Pustaka.

Dara, Y. P. (n.d.). PEMAHAMAN KONSEP BELAJAR UNTUK MENGASAH KECERDASAN MAJEMUK: PENDEKATAN PENELITIAN TINDAKAN Oleh: RAHMA, Pemahaman Konsep Belajar untuk Mengasah Kecerdasan Majemuk: Pendekatan Tindakan PENDAHULUAN Secara umum, kendala pada dunia pendidikan dasar untuk. 42-51.

Darma, I. P., \& Rusyidi, B. (2003). 37 pelaksanaan sekolah inklusi di indonesia. 223-227.

Djaali. (2007). Psikologi Pendidikan; cet ke-2. Bumi Aksara.

Fajra, M., Jalinus, N., Jama, J., \& Dakhi, O. (2020). Pengembangan Model Kurikulum Sekolah Inklusi Berdasarkan Kebutuhan Perseorangan Anak Didik. Jurnal Pendidikan, 21(1), 51-63. https://doi.org/10.33830/jp.v21i1.746.2020

Evelyn Wiliams English. (n.d.). Mengajar Dengan Empati.

Gardner, H. (2002). Multiple Intelligences. INTERAKSARA.

Gardner, H. (2003). Multiple Intelligences Kecerdasan Majemuk. Interaksara.

Harmoni, J., \& Theis, R. A. (2012). "Pengaruh Kemampuan Spasial Terhadap Hasil Belajar Matematika Siswa Kelas VII SMP Kota Jambi, 2:1. Jurnal Edumatika, 2(1).

Hasan, A. B. P. (2006). Psikologi Perkembangan Islami, Menyingkap Rentang Kehidupan manusia dari PraLahir Hingga Pasca Kematian; Cet ke-1. Raja Grafindo Persada.

Ibda, F. (2015a). PERKEMBANGAN KOGNITIF : TEORI JEAN PIAGET. 3, 27-38.

Ibda, F. (2015b). Perkembangan Kognitif: Teori Jean Piaget. INTELEKTUALITA, 3, 1.

Jasmine, J. (2007). Panduan Praktis Mengajar Berbasis Kecerdasan Majemuk; cet ke-1. Nuansa. Jujun S, S. (2001). Ilmu Dalam Perspektif. Yayasan Obor Indonesia.

-https://doi.org/10.18592/aladzkapgmi.v9i1.3011 
Lwin, M. (2005). How to Multiply Your Child's Intelligence, Cara Mengembangkan Berbagai Komponen Kecerdasan; cet ke-1. Indeks.

Ma'arif, M. A., \& Sulistyanik, E. D. (2019). Pengembangan Potensi Peserta Didik dalam Pembelajaran Pendidikan Agama Islam Berbasis Kecerdasan Majemuk (Multiple Intelligence). Al-Tarbawi Al-Haditsah: Jurnal Pendidikan Islam, 4(2), 81-105. https://doi.org/10.24235/tarbawi.v4i2.5216

Munif Chatib. (2010). Sekolahnya Manusia, Sekolah Berbasis Multiple Intelligences di Indonesia; cet ke-1. Kaifa.

Pratiwi, J. C. (2015). Sekolah Inklusi Untuk Anak Berkebutuhan Khusus: Tanggapan Terhadap Tantangan Kedepannya. Prosiding Seminar Nasional Pendidikan "Meretas Sukses Publikasi Ilmiah Bidang Pendidikan Jurnal Bereputasi,” November, 237-242.

Santoso, H. (2012). Cara Memahami dan Mendidik Anak Berkebutuhan Khusus. Gosyen Publishing.

Saputra, A. (2016). Kebijakan Pemerintah Terhadap Pendidikan Inklusif. Jurnal Ilmiah Tumbuh Kembang Anak Usia Dini, Vol 1 No 3.

Septianisa, S., \& Caninsti, R. (2016). Hubungan Self Efficacy Dengan Burnout Pada Guru Di Sekolah Dasar Inklusi Correlational Between Self-Efficacy And Burnout In Primary Inclusion Teacher. 4(1), 126-137.

Setiawan, A. R. (n.d.). Kecerdasan Majemuk Berdasarkan Neurosains Multiple Intelligences Based on Neuroscience. April 2020, 1-8.

Setiawati, L. (2019). Pembelajaran Berbasis Multiple Intelligences 140. 140-150.

Setiyowati, E. P., \& Arifianto, Y. A. (2020). Hubungan Kompetensi Pedagogik Guru dan Prestasi Belajar Siswa pada Mata Pelajaran Pendidikan. SIKIP Jurnal Pendidikan Agama Kristen, 1(2), 78-95. http://e-journal.sttikat.ac.id/index.php/sikip/article/view/57

SISDIKNAS, U.-U. (2003). Undang-Undang SISDIKNAS (Sistem Pendidikan Nasional). Tahun 2003 pada Pasal 5 ayat 2 dan Pasal 15.

Smith. (2006). Inklusi: Sekolah Ramah untuk Semua. Nuansa.

Sofiah, N. S. (2006). Pelaksanaan Pendidikan Inklusi, Tesis Pendidikan Khusus. Pasca Sarjana UPI.

Stainback, W. dan S. (1995). Support Network for Inclusive Schooling Independent Integrated Education. Paul H Brookes. 
Suarca, K. (2005). Kecerdasan Majemuk pada Anak. 7(2), 85-92.

Suharsono. (2004). Mencerdaskan Anak, Melejitkan Intelektual dan Spritual, Memperkaya Hasanah Batin,, Kesalehan serta Kreativitas Anak (IQ, EQ dan SQ, cet ke-1). Inisiasi Press. Sunardi. (2003). Pendekatan Inklusif Implikasi Managerialnya. Jurnal Rehabilitasi Remidiasi, Vol. 13.

Suparno, P. (2004a). Teori Inteligences Ganda dan Aplikasinya di Sekolah, Cara Menerapkan Teori Multiple Intelligences Howard Gardner, cet ke-2. Kanisius.

Suparno, P. (2004b). Teori Inteligensi Ganda dan Aplikasinya di Sekolah. KANISIUS.

Suparno, P. (2007). Konsep Inteligensi Ganda dan Aplikasinya di Sekolah: Cara Menerapkan Konsep Multiple Intelligences Howard Gardner. Kanisius.

Sustainable, J. I. (2019). No Title. 2(2), 176-197.

Tarmansyah. (2007). Inklusi ( Pendidikan Untuk Semua). Depdiknas.

Triposa, R., Arifianto, Y. A., \& Hendrilia, Y. (2021). Peran Guru PAK sebagai Teladan dalam Meningkatkan Kerohanian dan Karakter Peserta Didik. Jurnal Pendidikan Agama Kristen (JUPAK), 2(1), 109-126.

Zaluchu, S. E. (2020). Strategi Penelitian Kualitatif dan Kuantitatif Di Dalam Penelitian Agama. Evangelikal: Jurnal Teologi Injili Dan Pembinaan Warga Jemaat, 4(1), 28-38. https://doi.org/10.46445/ejti.v4i1.167 